\title{
速度場・温度場の光学計測に関する研究
}

\section{Measurement of Velocity and Temperature Field Using PIV and Two-color Laser Induced Fluorescence}

\author{
○松浦 这法・新潟大学
}

Fuminori Matsuura, Niigata University

\author{
藤濢延行・新潟大学可視化情胡研究さンター \\ 山本 浩樹・新潟大学大学院 \\ Nobuyuki Fujisawa, Niigata University, \\ Hiroki Yamamoto, Niigata University \\ Visualization Research Center
}

Key Words: Velocity, Temperature, Measurement, PIV, Two-color LIF

\section{1. 緒言}

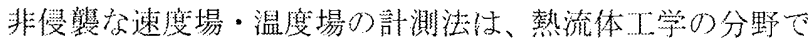
㕕く関心が持たれてきた。速度計測では粒子像流速測定法 (PIV法)、温度計測ではレー将誘起蛍光法（LIF法）などが しばしば用いられるが、速度場・温度場の同棱計測について

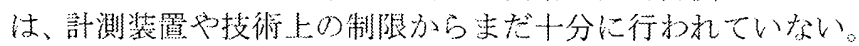
本研究では、速度場・温度場意之れぞれPIV法㧍上び2画LIF

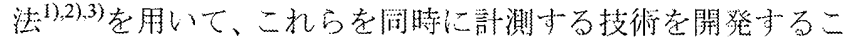
とを日的とした。また、一例として、オリフィス後流域の速 度場・温度場の計㵋結果定示吉。

\section{2. 実験装置と手法}

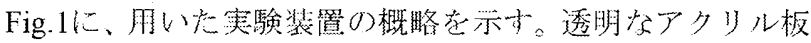
で作成した流路（内径 $d=52 \times 52 \mathrm{~mm}$ ○正方形断面）に才りフ

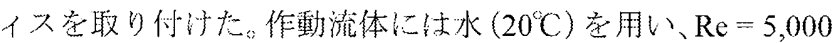
となるよう流した。下酒には熱源を設置し、加熱できるよう にした。本寒験では壁面温度は50兄とした。

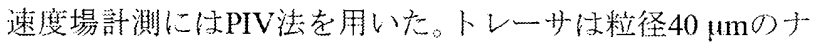
イロン粒子を用いた。流路の上方からミラーを介し、シート 状にしたNd-Yagレーザ $(532 \mathrm{~nm})$ を照射した。撮影には、1008 $\mathrm{x} 1018$ ビクセル、8ビットのモノクロームCCDカメラを用い た。

一方、温度場計測には2色LF法を用いた。染料には Rhodamine Bおよざ同110考用いた。光源にはAr-ionレーザ $(488 \mathrm{~nm})$ をシート状にして用いた。このしき、速度場計湘 と温庭場計測で、照明寸る領域が合致寸るよう配置した。撮 影には、680x 512ビクセル、16-bitモノクロームカメラ起二 台同期して用いた。ただし、备ビクセルは2 $\times 2$ どクセルの大 きさでBinningしている。各温麾計測用力メラでRhodamine B

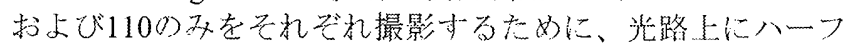
ミラー在瞗いて分光した。ただし、 Rhodamine B撮影用の力

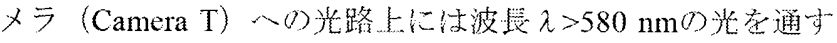
ロングパスフィルタを、Rhodamine 110 撮影网のカメラ

(Camera R）八の光路上には スフィル夕と、 $\lambda<550 \mathrm{~nm}$ の光を通すショートバスフィルタ

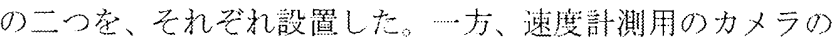
光路上には中心波長入 $=532 \mathrm{~nm}$ の㹨帶域バンドバスフィル タ老确㯰し、Nd-Yagレーザによって照明された粒子のみが撮 影されるようにした。

Fig.2仕、本研究に扮ける夕イミングチャートである。温度

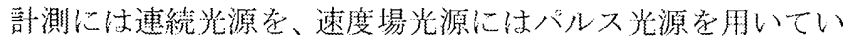
る。速度場誐測の撮影間隔は $\Delta t=3 \mathrm{~ms}$ 、温度場計測の露光時 間は100 msとした。速度場計測に用いた Nd-Yagレーザが、温

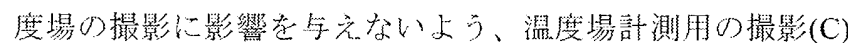

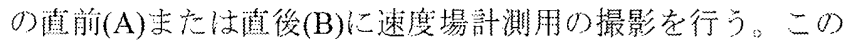
地め、正確には速度場已温度場の撮影タイミングは文ってい ない。しかし、平㚬倠を用いることでその影響索極力抑えた。

温度場部測では、宪騟に先立って一様温度場により検定画

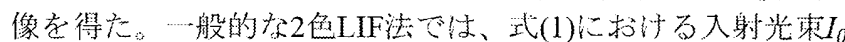

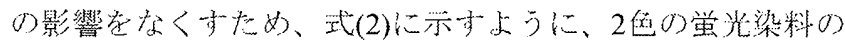

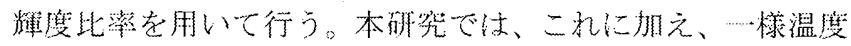

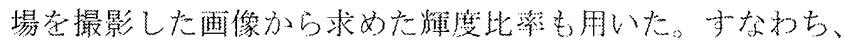

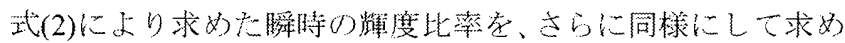
た一様温度場の輝度比滦で除した。

$$
\begin{aligned}
& I=I_{0} C \phi(t) \varepsilon \\
& I=\frac{I_{R h B}}{I_{R h H 0}}=\frac{C_{R h B} \phi_{R h B}(t) \varepsilon_{R h B}}{C_{R h H 10} \phi_{R h 110}(t) \varepsilon_{R h 110}}
\end{aligned}
$$

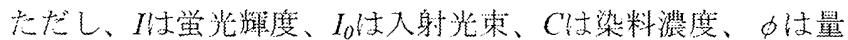

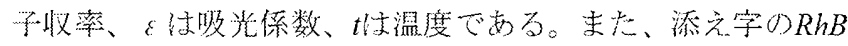

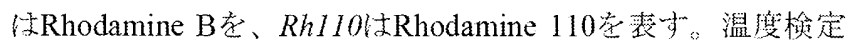
結果の一例学Fig.3に示夺。

\section{3. 実験結果と考察}

Fig.4は、瞬眭速度場ならびに溫度場である。 $x / d=1.0$ 扝よ び1.4近信の下面付近に遥流領域㹱形成されている。滑の周辺

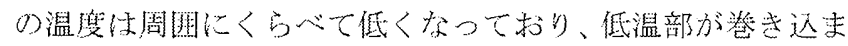
れていること分かる。

Fig.5は、㫢間平均速膺場ならびに温黀場で女る。上面では $x / d=1.0-1.5$ 付近、下面では $x / d=1.3-1.7$ 付近を境に、それぞれ 再循環領域代形成されて去り、上下面において再付着点位要 に碓りが晃られた。一方温度場からは、オリフィス真後に高 温領域が肜成されるこ上が分か力。

\section{4. 結言}

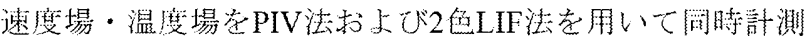
子万手法家䦕発した。また、一例ししてオリフィス後流の棓

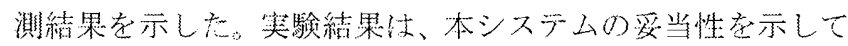
いる。

\section{参考文献}

1. J. Sakakibara and R. J. Adrian, Experiments in Fluids, 37 (2004), 331-340.

2. S. Funatani, N. Fujisawa and H. Ikeda, Measurement Science and Technology, 15 (2004), 983.

3. H. Yamamoto, F. Matsuura and N. Fujisawa, International Symposium on Fusion Tech (2009), 55. 


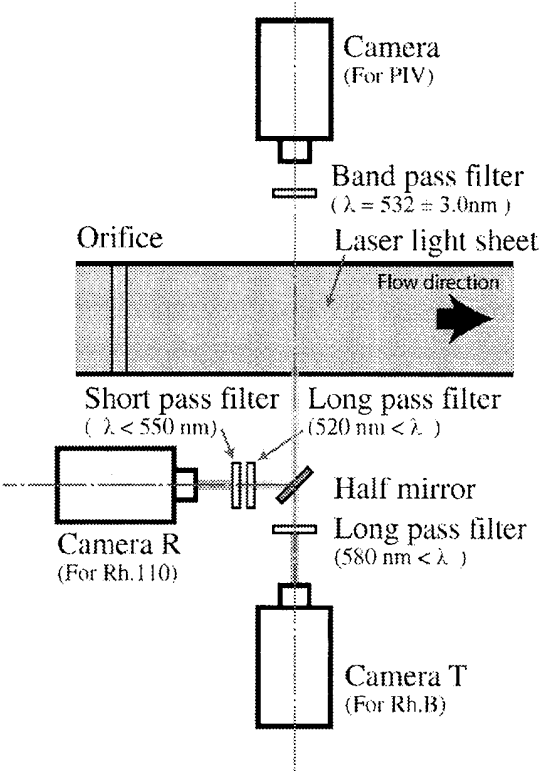

Fig.1 Experimental apparatus

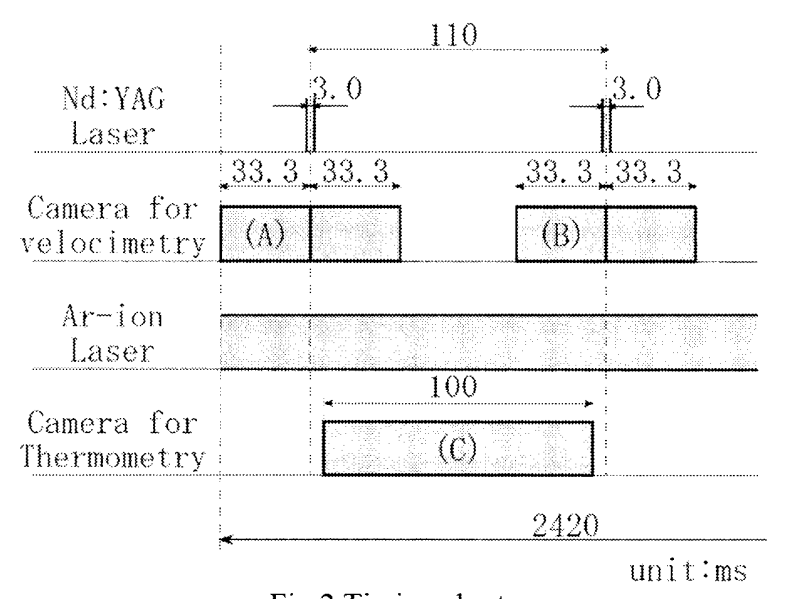

Fig. 2 Timing chart

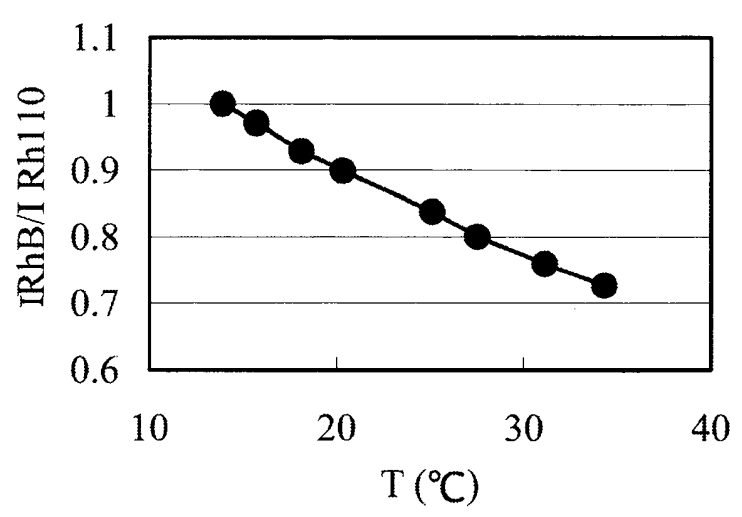

Fig. 3 Temperature calibration curve

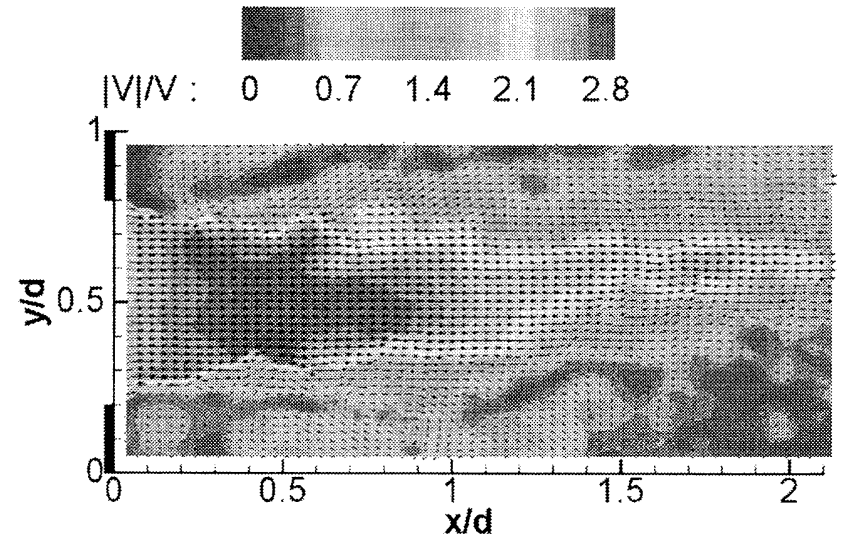

(a) Velocity field

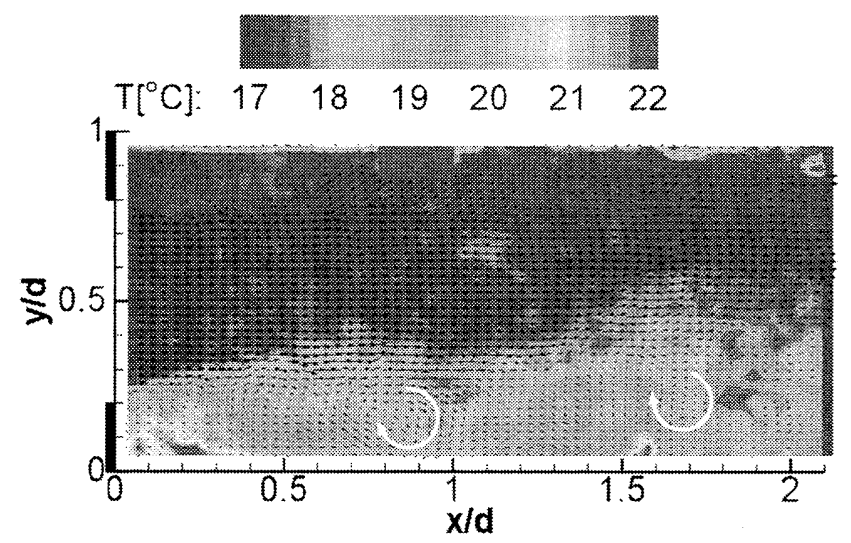

(b) Temperature field

Fig.4 Instanteneous velocity and temperature field

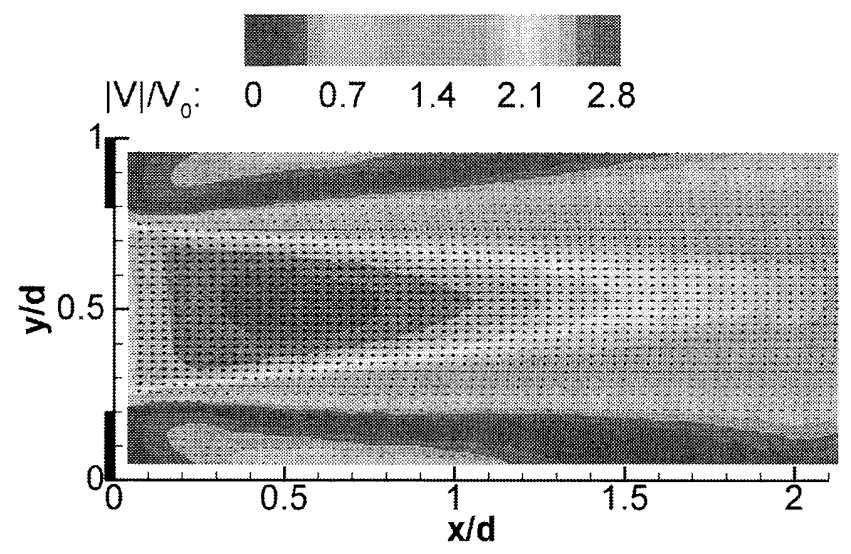

(a) Velocity field

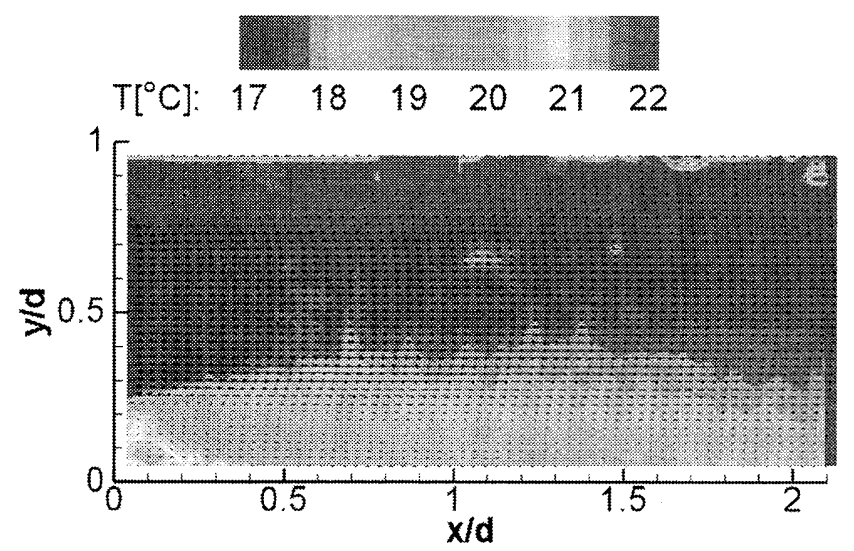

(b) Temperature field

Fig.5 Mean velocity and temperature field 